\title{
SJARIKAT SIMPAN-PINJAM DAN KONGSI OESAHA: RESPON ATAS MONETERISASI KOLONIAL
}

\author{
Dedi Arsa \\ Jurusan Sejarah Peradabab Islam IAIN Bukittinggi \\ E-mail: deddyarsya1987@gmail.com
}

Diterima: 1 November 2018

Direvisi : 12 November 2018

Diterbitkan: 31 Desember 2018

\begin{abstract}
This article examines the monetaryization and response of it in the archipelago, especially in Minangkabau. The compilation uses a drafting method known in general in modern historical methods: heuristics, internal criticism, external; interpretation; and explanation in the form of historiography. From this article produced: 1). The colonial presence intensified the money economy (monetaryization) into traditional societies which had previously not been so deeply penetrated into this system. The process went through two important periods of colonialism: the Forced Cultivation System \& Economic Liberalization. 2). The implication: stretching collective ties and new dependence on the colonial country with its individual money economy increases, and society experiences division which creates an anomaly, a sociologically shaken society. 3). This condition was responded to by the formation of savings and loan associations and business corporations or joint partnerships. This is to create a collective effort that has been eroded by a system of capital that tends to be individualistic. This business hardens in a more standard form / formulation: Cooperative. However. throughout history, cooperatives cannot grow, become dominant, in balancing the development of an increasingly established money economy.
\end{abstract}

Keywords: Monetaryisation, colonialism, local response, cooperatives.

\begin{abstract}
Abstrak
Artikel ini menelaah moneterisasi dan respon atasnya di Nusantara, khususnya di Minangkabau. Penyusunannya menggunakan metode penyusunan yang dikenal pada umumnya dalam metode penyusunan sejarah modern: heuristik, kritik intern-ekstern; interpretasi; dan ekplanasi dalam bentuk historiografi. Dari artikel ini dihasilkan: 1). Kehadiran kolonial mengintensifkan ekonomi uang (moneterisasi) ke dalam masyarakat tradisional yang sebelumnya belum begitu terasuki secara nyata ke dalam sistem ini. Prosesnya berlangsung lewat dua periode penting kolonialisme: Sistem Tanam Paksa \& Liberalisasi Ekonomi. 2). Implikasinya: ikatan kolektif merenggang dan ketergantungan baru kepada negera kolonial dengan ekonomi uangnya yang individual meningkat, serta masyarakat mengalami keterbelahan yang menciptakan keadaan anomie, suatu masyarakat yang terguncang secara sosiologis. 3). Kondisi ini direspon dengan terbentuknya perkumpulan simpan-pinjam maupun syarikatsyarikat usaha atau kongsi-kongsi bersama. Hal ini untuk menciptakan usaba kolektif yang telah terkikis oleh sistem kapital yang cenderung individualis. Usaha ini mengeras dalam bentuk/formulasi yang lebih baku: Koperasi. Namun. sepanjang sejarah, koperasi tidak dapat tumbub, menjadi dominan, dalam mengimbangi perkembanga ekonomi uang yang semakin mapan.
\end{abstract}

Kata kunci : Moneterisasi, kolonialisme, respon lokal, koperasi.

\section{Latar Belakang}

J. H. Boeke (1983), dalam bukunya, Prakapitalisme di Asia, memberi gambaran yang cukup memadai untuk menggambarkan bagaimana masyarakat Nusantara prakapital. Boeke menggambarkan bagaimana kondisi masyarakat prakapital di negara-negara Oriental. Disebutkan Boeke (1983: 17-18), lebih agak panjang dikutipkan:Para bangsawan memimpin kehidupan feodal tanpa mengerjakan pekerjaan ekonomi apa pun; mereka adalah pemimpin perang dan 
pemburu. Orang awam berproduksi. Orangorang awam ialah rakyat dengan sedikit perbedaaan kedudukan sosial, namun memiliki semangat kelompok yang kuat. Mereka emosional, dengan kemampuan intelektual yang kurang berkembang. Tidak disipilin dan kurang memiliki rasa ketetapan. Mereka cenderung menganggap kerja sebagai kejahatan, yang terpaksa harus dilakukan sedapat mungkin dijauhi dan dibatasi. Kerja mereka tidak teratur, dan umumnya lambat. Cara-cara kerja mereka tradisional. Sesungguhnya, individu pertama-tama merasa dirinya sebagai seorang anggota kelompok, dan dengan demikian berusaha untuk mengetengahkan dirinya sendiri sebagai berharga, dan apabila mungkin berusaha agar dikagumi oleh para anggota masyarakat.

Lebih lanjut menurut Boeke (1983: 18), pada sebagian masyarakat bumiputra, kepemilikan harta dikuasai secara bersama. Nyaris tidak dikenal kepemilikan individual dalam kebanyakan masyarakat di Nusantara. Artinya, kepemilikan semata bersifat kolektif. Apa yang menjadi hak milik, apakah berupa tanah maupun properti lainnya, merupakan hak milik kolektif, yang dikerjakan secara kolektif, dan hasilnya dimanfaatkan secara kolektif pula. Pada masyarakat seperti ini, sebuah masyarakat menghidupi dirinya sendiri. Nyaris tidak banyak kontak antar-masyarakat. Jika pun ada kontak perdagangan antarmasyarakat, hal itu cenderung disebakan karena perbedaan hasil produksi, bahwa tidak setiap masyarakat menghasilkan barang yang sama.Oleh sebab itu, sistem barter masih menjadi pandangan jamak pada masyarakat ini-terutama pada masyarakat rural yang jauh dari pusat urban.

Bagaimana sistem barter ini sendiri berlangsung? Menurut Yuval Noah Harari, dalam Sapiens: A Brief History of Humankind (2017: 246), masyarakat dengan sistem ini belum punya uang atau sistem uang. Mereka, kata Harari, “... mengumpulkan dan membuat hampir semua yang dibutuhkan, mulai dari daging sampai obat, dari sandal sampai sihir ... mereka berbagi makanan dan layanan dalam suatu model ekonomi gotong royong." Secara umum, gambaran masyarakat Nusantara sejalan dengan paparan Harari: "Sebagian besar orang terus hidup dalam kemunitaskomunitas kecil yang intim ... setiap warga desa adalah kesatuan ekonomi yang mandiri, dipelihara dengan gotong royong plus sedikit barter dengan pihak luar."

Lebih lanjut tentang gambaran ini, baik dikutip Boomgaard (1989: 98) dalam Anak Jajahan Belanda: Sejarah Sosial dan Ekonomi Jawa 1795-1886. Ia mengemukakan beberapa hal yang umum dipahami terhadap masyarakat Nusantara prakolonial, terutama dari kalangan etnolog Barat tradisional. Menurut mereka, masyarakat prakolonial Nusantara merupakan suatu penduduk yang terdiri atas sejumlah petani yang terlibat dalam produksi subsistensi. Mereka dianggap tidak tersentuh pasar dan uang. Mereka hidup dalam komunitas-komunitas tertutup dan mempunyai badan hukum dengan struktur yang harmonis, egaliter, dan demokratis. Mereka hidup dengan sikap sebagai abdi feodal terhadap kaum bangsawan pribumi. Lalu cara hidup serupa itu pelan-pelan digantikan oleh birokrasi kolonial dan perusahaan Barat berdasarkan sistem tenaga kerja paksa. Bersamaan dengan itu pula, terciptalah ekonomi dualistis (tandingan yang asli) yang dicirikan oleh kemandekan.

Begitulah gambaran umum aspek ekonomis masyarakat Nusantara prakolonial. Lebih tepatnya, itu adalah gambaran masyarakat yang kuno sekali dalam masyarakat Nusantara. Cenderung gambaran serupa ini mengabaikan perubahan sejarah. Gambaran itu tidak sepenuhnya sesuai dengan kondisi seluruh masyarakat Nusantara pada zaman prakolonial. Setidak-tidaknya, pandangan Boeke di atas itu adalah pandangan tradisional para peneliti Barat mengenai masyarakat 
ekonomi Indonesia prakapital. Padangan ini segaris dengan pandangan kebanyakan etnolog awal sebagaimana yang diungkapkan Boomgaard, bahwa pandangan itu keliru belaka sebab menganggap masyarakat Nusantara begitu terisolirnya, padahal kondisi sebenarnya tidaklah demikian deterministik.

Sekurang-kurangnya sejak zaman Hindu, munculnya kota-kota dan kerajaan-kerajaan serta perbaikan infrastrtuktur transportasi telah membawa peluang-peluang baru bagi masyarakat Nusantara. Kota-kota Hindu dengan penduduk padat menyediakan pekerjaan bagi tukang sepatu, dokter propesional/tabib, tukang kayu, tentara, para empu dari segala bidang pekerjaan, guru di pusat-pusat pendidikan (mandala) dst., di samping para pedagang dari segala tingkatan, mulai dari pedagang kecil, pedagang perantara, dan pedagang besar. Sementara desa-desa mendapatkan reputasi sebagai produsen komoditas-komoditas alam-tergantung kepada topografinya, iklim, dan perbedaan tanahnya.

Lalu dengan kemunculan Islam, sekurang-kurangnya dimulai sejak abad ke-13, kota-kota pelabuhan bercorak Islam telah memainkan peran yang menentukan dalam lalu lintas ekonomi kawasan. Lewat bandarbandar yang juga berfungsi sebagai ibukotaibukota kerajaan Islam itu, masyarakat Nusantara terhubung ke dunia perdagangan yang melibatkan banyak sekali bangsa: Arab, Cina, India, Persia, bahkan juga Eropa di masa yang lebih belakangan, maupun dengan sesama suku-bangsa di Nusantara ini sendiri. Usahausaha untuk memperoleh kekayaan telah berlangsung semarak masa ini. Masa-masa perdagangan pantai, masa 'kurun niaga' sebagaimana terjemahan atas judul buku Anthony Reid (1992: 72), telah menyulut intensitas masyarakat Nusantara untuk berusaha memperoleh kekayaan. Sistem barter hanyalah sistem yang masih diterapkan masyarakat-masyarakat suku di pedalaman yang betul-betul terisolir dari perdagangan pantai, sementara masyarakat Nusantara yang telah terhubung ke dalam sistem dunia betulbetul telah meninggalkan sistem pergadangan barter untuk dengan senang hati memasuki sistem ekonomi uang, di mana uang mulai digunakan secara luas sebagai alat tukar dengan berbagai varian atau jenisnya.

Yuval Noah Harari kembali dapat dikutip untuk menggambarkan dengan baik peralihan itu, tentang bagaimana sistem ekonomi barter tidak mungkin lagi diterapkan di tengah kondisi ekonomi masyarakat yang sudah kompleks: Sebuah ekonomi gotong royong tidak bisa berjalan ketika banyak orang yang asing satu sama lain berusaha untuk bekerja sama. Memberi bantuan gratis kepada saudara perempuan atau tetangga adalah satu hal, tetapi merawat orang asing yang mungkin tidak pernah memberikan balasan adalah hal yang sangat berbeda. Orang bisa rugi dalam barter. Sistem pertukaran ini hanya bisa efektif untuk pertukaran dengan produk terbatas. Barter tidak bisa menjadi basis bagi sebuah ekonomi yang kompleks." Gambaran ini akan mendapat pembenarannya yang lebih kuat jika kita kutip lagi apa yang diutarakan Bloomgard. Menurut Boomgaard (1989:16), secara umum pada periode ini intensitas sistem uang memasuki bilik-bilik masyarakat Nusantara belumlah tinggi sekalipun bukan pula daerah yang terisolir dari sistem moneter.

Tulisan ini akan melacak asal-usul moneterisasi dan respon atasnya di Nusantara, secara khusus di Minangkabau. Artikel ini adalah karya sejarah dengan spesifikasi tematik sejarah ide atau pemikiran tentang ekonomi, yang menelaah perkembangan gagasan tentang ekonomi masyarakat, termasuk bagaimana gagasan itu kemudian direalisasikan. Penyusunannya menggunakan metode penyusunan yang dikenal pada umumnya dalam metode penyusunan sejarah modern, yaitu meliputi empat tahapan: heuristik, berupa pengumpulan bahan/sumber; kritik sumber 
berupa kritik intern-ekstern; interpretasi berupa pengklasifikasian data-data dan mencari hukum kausalnya; dan eksplanasi dalam bentuk historiografi. (Lloyd, 1993: 12; Garaghan, 1984: 23). Tulisan ini sedapat mungkin melacak sumber-sumber tua dari yang tersedia dan dapat dilacak, semisal beberapa surat kabar dan berkala kolonial, tetapi rata-rata menggunakan sumber kedua. Telah ada juga beberapa tinjauan tentang topik yang serupa semisal karya Zed (2012), yang membahas tentang dilema ekonomi di dunia Melayu di tengah pusaran arus kapitalisme ekonomi. Nugroho (2001) secara lebih spesifik membahas penetrasi uang dalam sistem ekonomi tradisional, tetapi lebih memokuskan pembahasan ke masyarakat Jawa. Oleh sebab itu, sejauh ini, yang membahas respon lokal atas moneterisasi di Sumatra khususnya bagian tengah, secara umum belum terlihat mencolok.

\section{Kemunculan Ekonomi Kolonial: Moneterisasi}

Sistem pememilikan individual ini semata-mata kecendrungan yang diperkenalkan sistem kapital lewat Barat sebagai perpanjang-tangannya. Kehadiran kolonial mengintensifkan ekonomi uang ke dalam masyarakat tradisional yang sebelumnya belum begitu terasuki sistem ini. Jalurnya adalah lewat lorong-lorong yang telah dirintis oleh kolonialisme Barat, dan waktunya berbeda-beda di masing-masing daerah. Tetapi secara umum, lewat dua periode penting kolonialisme: Sistem Tanam Paksa \& Liberalisasi Ekonomi. Kita akan membicarakan lebih lanjut dua periode penting ini dalam sejarah ekonomi masyarakat Nusantara.

Di masing-masing daerah, kaum bumiputra berbeda-beda dalam memasuki periode ekonomi uang. Namun, secara umum, abad ke-19 adalah abad yang menentukan bagi penetrasi sistem ekonomi uang-kapital ke dalam masyarakat bumiputra, sekalipun pada masa VOC gejalanya telah juga muncul di beberapa daerah yang berada langsung di bawah kekuasaan kompeni itu. Dalam masyarakat tradisional Jawa, seluruh kepemilikian berada di bawah payung kerajaan. Terutama tanah, seluruhnya milik raja. Rakyat adalah abdi raja. Kehadiran VOC sejak akhir awak abad ke-18 di Jawa telah menggiring masyarakat Jawa terlibat dalam perdagangan kapital dunia dengan menanam tebu. Bermula dari perkebunan tebu, penanaman jati Jawa yang terkenal, hingga pembukaan pabrikpabrik gula, telah menggiring Jawa memasuki pasar dunia di bawah payung kapital Belanda. Lalu, ketika Inggris berkuasa, sejak Rafles, setidak-tidaknya, dia memperkenalkan sistem pajak kepala, orang-orang Jawa dihitung berdasarkan kepala-individual. Keadaan itu menguat semakin kokoh setelah Sistem Tanam Paksa dan Ekonomi Liberal dengan keikutsertaan pihak swasta secara luas diperkenalkan meluas bahkan tidak saja di Jawa, tetapi juga ke seluruh daerah-daerah di Nusantara. Abad ke-19 adalah penanda bagaimana secara merata dan massif masyarakat bumiputra menjadi terhubung ke dalam sistem ekonomi global-kapital, di mana kepemilikian individual menjadi penandanya, dan uang sebagai perantinya yang utama.

Sistem tanam paksa ini mula-mula dimulai di Jawa pada 1830. Pencetusnya bernama Johannes van de Bosch. Pendapat awalnya mengapa sistem ini diberlakukan karena adanya anggapan bahwa masyarakat Nusantara, terutama Jawa, kurang begitu mempedulikan hubungannya dengan perdagangan Eropa, dalam artian, apa yang mereka tanam di lahan-lahan mereka bukanlah produk-produk yang laku di pasar Eropa. Oleh sebab itu, orang-orang Jawa ini perlu dirangsang untuk menanam komoditaskomoditas unggulan yang laku di pasar dunia. Dalam bahasa Boomgard (1989:27)dikatakan bawah orang-orang Jawa ini dibujuk (dipaksa) 
"untuk menggunakan sebagian dari tanah garapannya (sampai paling kurang seperlima) dan sebagian dari tenaga kerjanya (juga seperlima, atau 66 hari kerja)". Mereka, petanipetani Jawa ini, diminta untuk menanam kopi, nila, dan gula. Tiga komoditas tersebut merupakan tanaman yang dibudidayakan secara luas para periode tanam paksa ini. Menurut catatan Boomgaard(1989:27), 6 persen jumlah sawah seluruhnya di Jawa pernah ditanami tanaman perdagangan untuk pasar Eropa berdasarkan sistem tanam paksa ini. Hari kerja petani di sawah jadi relatif jauh berkurang sebab mereka harus menyumbangkan tenaga mereka di perkebunan-perkebunan kopi, nila, maupun kopi. Kerja wajib mereka yang 66 hari sering harus melewati angka itu hampir dua kali lipatnya,hingga mencapai 120 hari dalam setahun harus dihabiskan bekerja di perkebunan dalam sistem tanam paksa.

Sistem ini mulai diperkenalkan secara perlahan sejak 1830 hingga 1835, tetapi dapat efektif di seluruh Jawa pada 1840. Sekalipun tidak di seluruh Nusantara sistem tanam paksa diperlakukan, atau pemberlakukannya berbeda-beda di masing daerah. Di Jawa sendiri, di Solo dan Yogyakarta, sistem ini tidak pernah diberlakukan, ini mungkin karena keduanya adalah daerah kerajaan. Di setengah Madura juga tidak pernah diberlakukan, bisa jadi karena beberapa daerah di Madura tidak cocok untuk budidaya tanaman ekspor tersebut. Di dataran tinggi Pasundan, di Priangan, diberlakukan sistem tanam paksa kopi tetapi juga diperkenalkan jenis-jenis tanaman lain selain yang tiga disebut tadi. Di Banguwangi, Kediri, Madiun, dan Pacitan telah diberlakukan sistem tanam paksa tetapi dengan versi yang sedikit telah diubah dari sistem yang ditetapkan awal. Bagi Jawa, akibat sistem tanam paksa ini cuku mencolok. Boogaard setidak-tidaknya mengemukakan beberapa dampak dari diperkenalkannya sistem ini bagi masyarakat Jawa secara luas. Beberapa di antaranya penting kita sampaikan di sini karena terkait langsung dengan tujuan kita menulis bab ini, tetapi beberapa lainnya dapat kita abaikan karena merupakan pembicaraan yang lain sekali dari topik buku ini secara umum.

Diambilnya seperlima sawah dan seperlima waktu bekerja petani dalam setahun untuk menanam tanaman-tanaman ekspor telah menyebabkan produksi tanaman tersebut jauh meningkat, tetapi dampaknya produksi padi dan tanaman perdagangan untuk pasar lokal menjadi mandek dan memburuk. Hal ini juga menyebabkan tingginya tekanan atas tanah, karena harus senantiasa berproduksi, tetapi yang paling terasa, menurut Boombaard (1989:28)adalah meningkatnya tekanan atas tenaga kerja yang harus mencurahkan seperlima bahkan lebih waktu dan tenaganya untuk bekerja di lahan-lahan pertanian yang ditanami tanaman ekspor. Sistem tanam paksa ini juga berdampak luas terhadap kebutuhan akan tenaga kerja. Permintaan akan tenaga kerja jauh meningkat—sekalipun ini tidak semata-mata karena akibat dari sistem tanam paksa, tetapi juga akibat dari meningkatnya ketergantungan akan kuli untum membangun jalan, jembatan, irigasi, pelabuhan, benteng, gedung, pabrik, [juga gudang], serta permintaan akan transportasi dan tenaga kerja di bidang industri. Tetapi, kita katakan, setengahnya adalah untuk kepentingan sistem tanam paksa ini juga. Pembangunan jalan dan jembatan, misalnya,

Meningkatnya moneterisasi, sekalipun diberi alas juga oleh Boomgaard(1989:28) bahwa bukan berarti sebelum 1830 Jawa adalah sebuah Naturalwirtschaft-maksudnya adalah suatu kedaan masyarakat yang naturalalamiah. Tetapi, sekurang-kurangnya seperti yang telah kita singgung juga terdapat bukti bahwa sistem tanam paksa telah membawa daerah-daerah Nusantara pada moneterisasi yang intensif sekali. Dampak yang kita sebutkan ini akan paling terasa nanti di 
masyarakat Minangkabau yang sebentar lagi akan kita bicarakan.

Di luar Jawa, semisal di Minangkabau, sistem tanam paksa mulai diberlakukan menjelang pertengahan abad ke-19. Sistem tanam paksa kopi sendiri dimulai sejak 1840, tidak berapa lama setelah dataran tinggi Minangkabau dapat dikatakan sepenuhnya takluk di bawah kekuasaan pemerintah kolonial Belanda. Setelah berakhirnya Perang Padri, ditandai dengan disepakatinya Plakat Panjang oleh pihak yang bertikai, Belanda telah keluar sebagai pemenang tunggal atas kemelut itu. Bagaimana kemudian sistem tanam paksa kopi itu diagendakan untuk Minangkabau, secara lebih gamblang penjabarannya ada dalam Dobbin (2008). Pada bab terakhir bukunya, Dobbin (2018, khususnya bab terakhir) mendedahkan bagaimana asal-muasal sistem tanam paksa kopi itu diberlakukan. Sistem tanam paksa kopi ini menandai masusknya ekonomi kapital Barat ke bilik-bilik pribadi orang Minangkabau. Sistem tanam paksa kopi, dicatat Dobbin (2008: 341-3) adalah bentuk campur tangan langsung pemerintah kolonial dalam ekonomi desa Minangkabau, yang menyebabkan desa-desa Minangkabau terhubung kepada masyarakat ekonomi global lewat terutama lewat tangan-tangan Barat. "Pejabat-pejabat Eropa sekarang langsung terlibat dalam ekonomi desa," sebut Dobbin, hal ini secara nyata menyebabkan kehidupan ekonomi kaum bumiputra "makin dimoneterisasi".

Keadaan ini semakin mengeras dan mengental ketika sistem ekonomi liberal diperkenalkan pemerintah kolonial Belanda pada 1870. Pada tahun tersebut, tepatnya 21 Juli 1870, Undang-undang Gula yang dikeluarkan pemerintah kolonial menyatakan bahwa sistem tanam paksa berakhir. Sementara Undang-undang Agraria yang dikeluarkan pada tahun yang sama memungkinkan masuknya modal swasta ke
Nusantara. Undang-undang tersebut menandai dimulainya masa ekonomi pintu terbuka atau ekonomi liberal yang di antaranya mempersilahkan perusahaan-perusahaan partikelir asing Eropa untuk menanamkan investasi seluas-luasnya dengan memberikan hibah tanah jangka panjang bagi perusahaanperusahaan yang bersedia. Menurut, banyak orang menganggap periode ini sebagai titik balik bagi kebijakan ekonomi kolonial Belanda, "Kebijakan konservatif perusahaan negara (Sistem Tanam Paksa) memberi peluang bagi fase liberal perusahaan swasta". Kebijakan ini sendiri lahir dari keluhan kaum humanis dan orang-orang yang menganut paham ekonomi liberal di negeri Belanda, yang melihat bahwa nyaris 5 windu Sistem Tanam Paksa berlangsung, kas Belanda memang telah sangat tertolong, tetapi sistem itu telah menurunkan derajat hidup pribumi jauh ke jurang kemelaratan. Wabah penyakit dan kelaparan menyebar dengan ganas terutama pada 1840an di Jawa Tengah. Masyarakat Nusantara di bawah sistem ini harus menanggungkan "Pajak langsung dan tidak langsung terlalu tinggi, upah tenaga kerja paksa yang tidak memadai, atau kurangnya perhatian terhadap kesejahteraan," demikian catat .

Dalam sistem ekonomi yang baru, modal swasta diizinkan untuk menyewa tanah kosong untuk jangka panjang selama 75 tahun. Modal swasta juga diberi peluang untuk menyewa tanah garapan dari para penduduk. Kebijakan ini bisa jadi terdengar memberi harapan di atas kertas. Namun, pada praktiknya, bagi masyarakat bumiputra sistem ini tidak lebih bagai lepas dari mulut buaya masuk ke mulut harimau. Dalam pandangan Hatta, sistem ekonomi kolonial Belanda itu, yang didukung/dibantu oleh kaum aristokrat dalam sistem feodalisme di dalam negeri dan pihak-pihak swasta asing tertentu sebagai komprador pihak kolonial Belanda. Penjajahan Belanda di Indonesia di bidang ekonomi berintikan modal kolonial (koloniaal-kapitaal) 
yang bermula dari kolonialisme VOC dan cultuurstelsel, pelaksanaan Undang-Undang Agraria 1870 sampai beroperasinya investasi swasta asing lainnya dari benua Barat (Hatta, dalam Sritua Arif, 2012: 1-2). Bung Hatta mengemukakan keadaan struktur sosialekonomi pada zaman kolonial Belanda di Indonesia yang menunjukkan golongan rakyat pribumi yang merupakan mayoritas menempati stratum terbawah dalam struktur sosial-ekonomi. Ekonomi rakyat di mana massa pribumi menggantungkan hidup mereka berada dalam posisi tertekan sebagai stratum terbawah dalam konstelasi ekonomi.

Lalu apa imbasnya bagi masyarakat bumiputra akan peralihan itu? Akibatnya cukup fatal. Arsa (2018: 165-6) memaparkan implikasi dari peralihan ini, dengan menuliskan bahwa ikatan kolektif di mana prinsip-prinsip ekonomi berjalan secara komunal, yang menjadi penanda ekonomi masyarakat prakapital, merenggang dalam masyarakat. Sementara di sisi lain ketergantungan baru kepada negera kolonial dengan ekonomi uangnya yang individual meningkat. Sebagai catatan untuk memperkuat, hal ini menjadi problem-problem yang banyak digarap novelnovel sebelum perang dalam sejarah sastra Indonesia. Keterbelahan masyarakat ini menciptakan keadaan anomie (meminjam terminologi Durkeheim), suatu keadaan peralihan di mana nilai-nilai dan norma-norma ditinjau kembali dan seolah-olah kehilangan pengaruhnya sama sekali. Kondisi ini bisa berakhir pada maraknya perilaku menyimpang, semisal kriminalitas atau kegilaan-dengan bunuh diri sebagai puncaknya. Anomie sendiri sejajar dengan gejala sakit jiwa, "diakibatkan oleh perubahan-perubahan masyarakat dan kebudayaan yang sangat dinamis," tulis J.B.A.F. Mayor Polak (1964: 141).

Arsa (2018: 165-6) menganalisis novelnovel zaman itu yang bisa dirujuk untuk menggambarkan kondisi tersebut. Kita ingat roman Aman Dt. Madjoindo, Tjerita Boedjang
Bingoeng yang tidak begitu terkenal (jika dibandingkan dengan romannya yang lain seperti Si Doel Anak Betawi yang ramai dibicarakan). Dalam roman ini, perkembangan kapitalisme kolonial mengantarkan masyarakat Indonesia pada semacam 'kegilaan'. Kaum pribumi dituntut untuk bergerak mengikuti gelombang-gadang ekonomi uang; bagaimana harus punya dan memiliki benda-benda material dari produksi global. Ini menciptakan depresi sendiri bagi masyarakat yang sebelumnya hanya menyerahkan hak milik pada sistem komunal, pada kepemilikan puak. Ramon Guillermo (2014) menyebut novel ini sebagai penggambaran yang sempurna tentang bagaimana konsep 'uang' masuk ke tengah masyarakat tradisional. Melani Budianta (2002), berhasil menelaah novel ini sebagai perwujudan bagaimana sistem uang memasuki dunia masyarakat ekonomi tradisinoal, yang berefek mengguncangkan tatanan lama mereka. Tokoh-tokoh dalam novel-novel sebelum Perang merepresentasikan hal yang nyaris mirip. Tokoh lain dalam novel yang lain: Samsu, dalam Sitti Nurbaja, berusaha bunuh diri karena patah hati. Aziz yang kaya-raya, dalam Tenggelamnya Kapal van der Wijck, jatuh miskin dan bunuh diri. Laminah, dalam Take Putus Dirundung Malang, bunuh diri karena tidak sanggup melanjutkan hidup dalam berbagai penderitaan; juga Mansur, dalam roman yang sama, bunuh diri dengan menceburkan diri ke laut karena selepas keluar dari penjara, lingkungan sosial tidak lagi menerimanya. Hanafi, dalam Salah Asuban, mati dengan cara meminum 4 butir sublimat; dia bunuh diri karena merasa tersisih dari lingkungan sosial-tradisionalnya.

Yuval Noah Harari (2018: 287) berikut ini cukup cocok untuk menggambarkan keadaan di atas ini: "Mereka sudah kehilangan kultur lokal yang dicintai, tetapi mereka belum dibolehkan untuk mengambil bagian yang sama dari dunia imperium. Sebaliknya, kultur 
adopsi mereka terus memandang mereka sebagai barbar."

\section{Respon atas Moneterisasi Sistem Kapital}

Kondisi-kondisi sosial-ekonomi masyarakat bumiputri seperti di atas itulah barangkali yang memicu gagasan-gagasan tentang koperasi muncul dari Bapak Pendirinya, Mohammad Hatta. Koperasi secara resmi terbentuk pada 1947. Tetapi, dalam masyarakat Indonesia sendiri, koperasi telah ada jauh sebelum itu. Bagaimana perkembangan bentuk atau model koperasi sebelum Indonesia merdeka?

Di perkotaan, khususnya di kota-kota di Jawa, koperasi terutama berupa perkumpulan simpan-pinjam. Perkumpulan ini mulai marak sejak diperkenalkannya Sistem Tanam Paksa di Jawa pada 1830, ketika para petani Jawa dipaksa menanam tanaman ekspor seperti gula, nila, dan kopi untuk pasar dunia. Kondisi baru ini telah "memperluas jangkauan perekonomian uang hingga ke pedesaan di Jawa dan langsung mengarah pada pertumbuhan kota-kota besar maupun kecil," begitu catat John Ingleson. Sekalipun kita tidak tahu berapa persis jumlahnya, tetapi pertumbuhan ini semakin dipercepat ketika Sistem Tanam Paksa berakhir. Lalu setelah itu Masa Liberalisasi Ekonomi dimulai pada 1870 dengan dibukanya kran bagi modal asing oleh pemerintah kolonial Belanda. Hal ini menyebabkan secara nyata "kenaikan jumlah populasi terus-menerus dan penutupan tanah perbatasan Jawa mendorong dan memaksa orang-orang untuk mencari pekerjaan di luar desa," kata John.

John menulis sebuah artikel berjudul "Perkumpulan Simpan Pinjam Masyarakat", yang jika kita ikuti alur berpikirnya, akan kita temukan bahwa cikal-bakal koperasi di Indonesia tidak datang dari Eropa, tidak juga datang dari hanya gejala pedesaan di Indonesia. Tetapi, ini juga merupakan gejala lokal masyarakat Indonesia sendiri di tengah gejolak kehidupan urban, bermula dari masalah yang mengebat masyarakat perkotaan awal. Ia lahir dan merupakan bagian dari “masa perekonomian uang” (John, 2013: 240), dan perkumpulan simpan pinjam adalah bentuknya yang paling awal. Ini adalah model bank yang sederhana kalau boleh dikatakan yang berkembang di kota-kota Indonesia awal. Menurut John(2013: 241), belum diketahui sejak kapan dan bagaimana perkumpulan simpan pinjam masyarakat muncul pertama kali di masa penjajahan. Namun setidaktidaknya didapat keterangan bahwa perkumpulan seperti itu merupakan bagian dari kehidupan bagi sebagian masyarakat kebanyakan di kota-kota besar maupun kecil pada seperempat abad terakhir abad ke-20. John menulis:

"Pada 1910an, perkumpulan masyarakat ini biasa ada di tempat-tempat kerja dan kampung, bagian dari wilayah perkotaan yang seringkali kurang terawat di mana para buruh upahan dan keluarganya tinggal".

Gambaran perkumpulan simpan pinjam adalah "Sejumlah besar orang bergabung dan sebagian dari mereka mengurus sejumlah uag yang berarti”. Bagi banyak orang, mereka [perkumpulan ini] "merupakan sokongan berguna bagi upaya mengatasi kehidupan sehari-hari dengan pendapatan yang kecil tanpa kemapuan menabung dan selalu adanya dihadapkan pada ancaman kehilangan pekerjaan, sakit, ataupun kematian.

John (2013: 241)selengkapnya menulis:

"Perkumpulan simpan pinjam masyarakat di daerah perkotaan Indonesia yang paling awal adalah perkumpulan masyarakat untuk dana jaminan kematian. Membeli tempat pemakaman dan membiayai sejumlah upacara yang dibutuhkan di perkotaan merupakan pengeluaran utama bagi orang-orang yang hidupnya hari demi har berasal dari upah rendah dan sering kali tidak menentu." 

lagi:

John (2013: 242)ada baiknya kita kutip

"Perkumpulan masyarakat jaminan kematian ini merupakan urusan kecil. Mungkin diorganisasi oleh pemimpin kampung atau mandor di tempat kerja, mereka mengharuskan anggotanya membayar sedikit uang sebagai iuran secara rutin dengan imbalan berupa jaminan sejumlah uang untuk biaya kematian anggota keluarga."

Masyarakat Nusantara tradisional sesungguhnya memang telah memiliki semacam organisasi desa ataupun perkumpulan dan perkongsian untuk saling membantu menghadapi masa-masa sulit. Dalam bentuk yang lebih formal, perkumpulan-perkumpulan ini berbentuk 'sarikat' ekonomi dengan berbagai modelnya, ada yang berkembang di daerah perdagangan dan kawasan buruh, ada juga yang bertumbuh di wilayah pertanian di antara kalangan para petani maupun pekebun; yang pertama ada di kota-kota kolonial yang baru tumbuh seiring bangkitnya gairah ekonomi, yang kedua berada di wilayah pedesaan yang agak berjarak dari wilayah-wilayah urban.

Pertama-tama, kita akan membicarakan koperasi yang berkembang di pedesaan. Mengenai hal tersebut, John Ingleson (2013: 90), sejarawan Inggris, mencatat dalam artikelnya "Perkumpulan Simpan Pinjam Masyarakat" dalam buku Perkotaan, Masalah Sosial, dan Perburuban di Jawa Masa Kolonial:

"Desa di Indonesia boleh jadi selalu memiliki struktur informal yang membantu masyarakatnya pada saat dibutuhkan-untuk membiayai acara pernikahan, pemakaman atau membantu selama masa perawatan sakit serta musibah keluarga lainnya."

Nama-nama perkumpulan yang dimaksud John itu bisa bermacam-macam di masing-masing daerah. Kadang-kadang sesuai dengan bahasa daerahnya masing-masing.
Tetapi prinsipnya adalah sama; memegang prinsip kekeluargaan dalam membantu sesama-maksudnya dalam membantu anggotanya untuk menyelesaikan persoalannya. Di nagari-nagari di Minangkabau, contohnya, dalam sebuah laporan surat kabar tahun Madjalab Tani 1927 dikatakan:

"Dipergaoelan hidoep boemipoetra diMinangkabau ini dari dahoeloedahoeloenja soedah kedapatan bekerdja bersama-sama (tolong-bertolong) itoe. Seboeah misal jang terang dan sampai sekarang masih banjak dilazimkan orang, ialah waktoe mengerdjakan sawah, dan menegakkan roemah d.l.l.

Di Minangkabau sejak kurun ini telah diadakan semacam perkumpulan intranagari berupa Lumbuang Nagari, yang tersebar di masing-masing nagari, dengan beragam nama di tiap-tiap nagari NNagari sendiri adalah struktur pemerintahan terendah di Minangkabau, setara dengan desa di Jawa atau mukim di Aceh]. Kita tidak tahu apakah pada prakolonial telah juga ada semacam keasadaran seperti ini, belum dapat kita terangkan soal yang ini. Lumbuang Nagari sendiri adalah semacam bank sederhana tempat di mana anggota kaum dan nagari menyimpan uang untuk kemudian dipergunakan sewaktu-waktu ketika ada musibah-musibah tertentu atau hajatan-hajatan penting tertentu.

Lumbung Nagari ini begitu bermakna perannya pada beberapa kejadian bencana, yang mempelihatkan andilnya dalam memberikan bantuan. Ada banyak contoh di mana keberadaannya secara efektif dapat membantu anggotanya yang kesulitan. Beberapa kebakaran yang terjadi di Minangkabau sepanjang 1920an dan 1940an misalnya, sebagaimana yang dicatat Madjalah Tani-sebuah majalah pertanian yang dikeluarkan oleh Dienst Landbouw di Bukittinggi, yang janggauan penyebarannya cukup luas untuk kalangan para petani di Sumatra bagian tengah-para korban 
kebakaran dapat terselamatkan hayat-hidupnya berkat peran aktif Lumbung Nagari di masingmasing nagari. Selengkapnya dicatat:

"Pengoeroes-pengoeroes loemboeng desa di Kota Nan Gadang dari jang rendah sampai jang tinggi soedah mengambil kepoetoesan menghapoeskan segala oetang orangorang jang ditimpa bahaja kebakaran itoe sama sekali".

Lumbung Nagari itu begitu penting artinya di tengah kondisi-kondisi darurat atau krisis yang menimpa sebuah nagari. Atas perannya ini, kehadirannya di nagari-nagari dipuji-puji surat kabar:

"Boekankah ketentoean loemboeng desa itoe soeatu jang haroes dipoeji dan dihargakan tinggi oleh kita semoeanja?"

Di daerah pedesaan pula, dalam bentuknya yang lebih kompleks, perkumpulan atau sarikat-dalam artian [semacam] koperasi-tercacat tumbuh dengan cukup pesat pada kurun sebelum kemerdekaan ini. Hal ini lebih dari sekadar perkumpulan berupa perkongsian biasa yang dimaksud tadi, tetapi telah berbentuk koperasi yang kita pahami, dalam pengertian sebagaimana yang tertulis dalam surat kabar Madjalah Taniberikut ini:

"Sedangkan koperasi dipakaikan, apabila bermaksud akan mempergoenakan tenaga bersama dalam hal: hendak memperoleh modal, mengadakan barang-barang oentoek peroesahaan, perkakas-perkakas dam benda-benda bergoena boeat hari-harian, mendjoealkan hasil-hasil keboen, mengoesahakan dan menghasilkan barang-barang perniagaan dan mengadakan oeang-oeang oentoek biajabiaja jang datangnja tiba-tiba sadja seperti kematian, kebakaran, keroesakan hewan d.1.l. Disini boekanlah sematamata bekerdja bersama-sama yang dikemoekakan, tetapi lebih lagi bersekoetoe dan bersatoe, soepaya bertambah kekoeatan dimata orang lain."
Untuk contoh yang lebih kompleks tersebut, Sarikat Kebun Pandai Sikek, misalnya, adalah prototipe yang tepat. Lagi-lagi di Minangkabau, koperasi ini adalah yang tertua di Sumatera Tengah yang didirikan dan dikelola oleh kaum bumiputra. Koperasi ini merupakan, "... barangkali jang tertoea diAlam Minangkabau". Perkumpulan ini mulai berdiri pada 1915, dengan anggota para petani. Sejak berdiri, koperasi ini telah berkembang dengan keuntungan yang besar, dan mendapat pujian-pujian di suratkabar. Dalam sebuah artikel di suratkabar berjudul "Sarikat Kaboen Pandai Sikat (1915-1928)", dikatakan bahwa koperasi ini telah menjadi prototipe keberhasilan sebuah koperasi yang digagas masyarakat lokal. Koperasi ini, menurut berita suratkabarMadjalah Tani, "Seboeah tjontoh, jang patoet sekali ditiroe oleh semoea orang!" Kongsi ini pada 1927 sudah ada mempunyai 10.000 batang para yang memberi hasil dan lebih dari 10.000 batang yang baru berumum 1,5 tahun.

Koperasi Sarikat Kebun Pandai Sikek ini sendiri adalah sebuah koperasi yang didirikan oleh orang-orang dari Nagari Pandai Sikek, yang pada masa itu berada di bawah pemerintahan administratif Onderafdelng Padang Panjang. Sebaimana dicatat sebuah pemberitaan: "... seboeah koperasi beroesaha tanah dari orang2 negeri Pandai Sikat, onderafdeeling Padang Pandjang." Proses pendirian koperasi ini bermulai dari gagasan dan pendirian dari Datoek Radjo Nando, seorang penghulu Suku Sikumbang di Pandai Sikek. Sang Datuk telah cukup lama merantai ke Malaka dan terbilang sukses di tanah rantau. Sekembali dari Malaka dia meninjau kampung halamannya. Pada 1915 dia lalu mendirikan koperasi tersebut. Dia diikuti oleh empat orang lainnya yang bernama: Datoek Sinaro Pandjang, Datoek Radjo Endah, Sidi Katib, dan Labai Bagindo Besar. "Orang jang berlima inilah sebenarnja, jang merintis djalan 
boetat koperasi itue," begitu kata laporan surat kabar.

Sejak didirikan tahun 1915 itu, anggota koperasi ini terus meningkat dari tahun ke tahun. Pada 1919 anggotanya tercatat sejumlah 36 orang, setahun kemudian anggotanya sampai 50 orang. Rata-rata anggotanya adalah orang Pandai Sikat, sekalipun ada juga yang dari luar nagari itu, seperti 2 orang dari Koto Laweh, dan ada juga yang dari Koto Baru. Uang iuran diambil rata-rata $\mathrm{f30}$ - sebulan. Sempat nyaris collapse pada tahun 1923-1924 akibat harga komoditas pertanian yang menukik tajam, setelah itu perkumpulan ini bangkit lagi. Sampai tahun 1927, keuntungan bersih koperasi ini sudah mencapai f6.616.56. "Tahoen jang lepas, kalau dihitoeng keoentoengan perserikatan lebih dari 60\%," demikian dicatat berita suratkabar Madjalah Tani tahun 1927. Sebagaimana koperasi pada umumnya yang kita kenal kini, dari seluruh laba yang dihasilkan perkumpulan ini, 15\% di antaranya disisihkan untuk pekerluan memperluas usaha. Sementara $85 \%$ laba yang tersisa, dibagi-bagi untuk seluruh anggota.

Akibat keberhasilan koperasi ini, beberapa daerah juga mulai mengembangkan koperasi dalam bidang yang sama. Daerah yang berikutnya tercatat hendak merintis koperasi adalah Kayu Tanam. Catat suratkabar: "Di-Salodako (Kajoe Tanam) orangpoen soedah meniroe teladan itoe dengan mendirikan poela seboeah koperasi." Tanaman yang hendak diusahakan koperasi di Kayu Tanam ini bukan saja para (karet) tetapi telah juga mulai mengusahakan tanaman lain di antaranya kopi. "Tanaman yang akan ditanam, ialah para dan barangkali diantaranja kopi." Selain Kayu Tanam, di daerah AgamLubuk Basung juga telah pula diancang-ancang untuk mendirikan koperasi dalam bidang sejenis. Menurut laporan Madjalah Tani: " ... di Loeboek Basoeng (Padang Kalam Sitanang) soedah poela ada seboeah lagi koperasi sematjam itoe".
Di Bonjol, sebuah koperasi tumbuh dengan menggembirakan. Serikat Setia Bondjol, telah mendapat rechtpersoondari pemerintah lewat sebuah beshit. Koperasi ini dipimpin oleh Ahmad Marzoeki, dan dilaporkan telah mempunyai sebuah toko yang bernama 'Toko Cooperatie Setia Bondjol'. Tercatat, koperasi ini tumbuh dengan cukup baik. Pada 1922, penjualan di toko 1716.39 gulden, angka yang cukup besar pada saat itu, dan dari tahun ke tahun pendapatan toko itu "selaloe naik-naik sadja". Di samping itu koperasi ini telah pula punya sebuah perkebunan (onderneming), dan ketika berita itu ditulis, tengah memohon permintaan seluas 600 hektar tanah di Bonjol guna memperluas perkebunan. Yang lebih menggembirakan, Serikat ini memiliki sebuah organ, surat kabar, Soeara Bondjol yang menyiarkan berita-berita tentang negeri itu (Pandji Poestaka, 1 Juli 1923).

\section{Epilog: Perkembangan Lebih Lanjut Menjelang Indonesia Merdeka}

Perkumpulan-perkumpulan simpanpinjam terus berkembang pada kurun awal abad ke-20. Mulai dari perkumpulan masyarakat untuk jaminan dana kematian yang sederhana, kemudian berkembang menjadi asuransi dan dana pensiun, asuransi pengangguran serta badan-badan usaha tabungan dan peminjaman. Lebih jauh lagi, terdapat sejumlah koperasi, yang menyediakan sandang, pangan, dan barang-barang rumah tangga, baik yang baru atau bekas. Hal ini dilakukan guna "mengurangi biaya hidup dari masyarakat biasa dengan cara menghindari toko-toko lokal, terutama toko orang Cina."

Apalagi, kemunculan organisasiorganisasi pergerakan membuat jumlah organisasi simpan pinjam masyarakat meningkat pesat. Kurun tersebut adalah kurun di mana "orang-orang Indonesia mencari jalan untuk meringankan permasalahan sosial dan ekonomi dari hidup di Jawa yang dengan cepat 
menjadi perkotaan di bawah pemerintahan negara kolonial yang tidak ada struktur kesejahteraan sosialnya." Perkumpulanperkumpulan simpan pinjam diciptakan oleh organisasi sukarela dan oleh kelompokkelompok kecil individu yang bersatu guna mengatasi masalah tersebut dengan cara yang berbeda, yaitu mendorong kerjasama melalui penyatuan sumber daya yang ada. Dan di antara perkumpulan-perkumpulan simpan pinjam yang ada, yang paling kuat dan besar pada kurun ini adalah perkumpulan simpan pinjam yang didirikan dan dikelola oleh para buruh.

John (2013: 242)menulis:

"Perkumpulan simpan pinjam masyarakat yang paling besar dan paling kuat secara finansial adalah yang dikelola oleh sarekat buruh pemerintahan dan yang mayoritas anggotanya adalah pekerja yang dibayar lebih tinggi dan lebih terampil .... Sarekat buruh menarik puluhan ribu pekerja di perkotaan pada 1910an, 1920an, dan 1930an."

Selain adanya perkumpulan simpan pinjam sebagaimana yang telah kita uraikan tadi, banyak lagi model perkumpulan yang mirip koperasi, mulai dari yang didirikan oleh orang pribumi maupun yang digagas oleh orang Belanda, baik yang digagas kaum saudagar maupun yang diperuntukkan bagi para pegawai negeri. Untuk yang terakhir disebutkan, salah satu modelnya yang paling awal bahkan dimulai lebih awal lagi, sejak tahun 1896, yang dipelopori oleh seorang pegawai negeri (ambtenaar) bernama Patih R. Aria Wiria Atmaja di Purwokerto. Sang pamong mendirikan sebuah bank untuk para pegawai negeri (priyayl) Jawa (Dahlan Djazh, 1980: 16).

Keinginannya untuk mendirikan lembaga keuangan berbasis koperasi ini didorong oleh keprihatian dan keinginan untuk menolong para pegawai yang makin menderita karena terjerat oleh lintah darat yang memberikan pinjaman dengan bunga yang tinggi. Maksud Patih tersebut untuk mendirikan koperasi kredit model seperti di Jerman, demikian kata sebuah sumber, tapi kita tidak tahu apakah betul model seperti Jerman yang menjadi rujukan jika mengingat sejak kapan sang Patih pergi studi banding ke Jerman atau pernah mempelajarinya melalui bahan bacaan yang tersedia ketika itu, memang perlu dibuktikan kembali.

Cita-cita dan semangat awal tersebut selanjutnya diteruskan oleh De Wolffvan Westerrode, seorang Asisten Residen Belanda. Dia mengunjungi Jerman dan menganjurkan mengubah Bank Pertolongan Tabungan yang sudah berdiri di Hindia menjadi Bank Pertolongan, Tabungan, dan Pertanian. Dalam karangannya yang dimuat dalam Tijdschrift voor Nijverheid en Handel tahun 1896, De Wolffvan Westerrode menuliskan mengenai cara kerja koperasi yang kemudian menjadi sebuah bank, yang diberi nama Poerwokertasche Hulp itu. Bank ini menjadi contoh yang pertama bagi Volks Credit Bank segala kebutuhan manusia, baik sandang, pangan, dan papan dapat terpenuhi dengan takaran ekonomi (Margono Djojohadikoesoemo, 1941: 9). Sementara dari kalangan kaum pergerakan terdidik bumiputra, pada tahun 1908, Budi Utomo yang didirikan oleh Dr. Sutomo memberikan peranan bagi gerakan koperasi untuk memperbaiki kehidupan rakyat. Pada tahun 1915 dibuat peraturan Verordening op de Cooperatieve Vereeniging, dan pada tahun 1927 Regeling Inlandschhe Cooperatieve. Pada tahun 1927 dibentuk Serikat Dagang Islam, yang bertujuan untuk memperjuangkan kedudukan ekonomi pengusah-pengusaha pribumi.

Pendirian koperasi sebagai usaha untuk membebaskan masyarakat dari cengkeraman rentenir dan tengkulak merupakan tujuan yang umum ketika itu. Rentenir menggunakan sistem riba yang besar dalam urusan pinjammeminjam telah menjadi penyebab yang menyengsarakan rakyat. Masyarakat sangat 
tergantung pada renterir (terutama rentenirrentenir lokal) pada masa-masa krisis atau pada suatu keadaan mendadak; pada kondisi ini orang-orang tidak punya tempat lain untuk mengadukan halnya selain kepada rentenirrentenir itu sebab ketiadaan tempat meminjam. Untuk itulah gerakan-gerakan koperasi berupa perkumpulan simpan pinjam dan sejenisnya, digalang demi melindungi masyarakat, secara bersama-sama menciptakan proteksi yang saling menguntungkan terutama pada masamasa sulit. Inilah pula yang menyebabkan koperasi di kalangan kaum bumiputra tumbuh dengan pesat pada masa ini.

John (2013: 243)tentang ini menulis:

"Mereka mungkin masyarakat perkotaan pertama dengan pengamalam masa menabung ketika normal dalam mengatasi kebutuhan mendadak terhadap uang tunai adalah meminjam dari rentenir lokal ... Anggota perkumpulan masyarakat jaminan kematian yang awal ini saling mengenal satu sama lain secara pribadi sehingga bisa memliki keyakinan pada para pengelola yang memegang uang dengan rasa percaya .... Uang tersebut mungkin diinvestasikan di rekening tabungan yang dijalankan kantor pos milik pemerintah atau mungkin dipnjamkan kepada para anggota unutk pengembalian dengan bunga. Jumlah uangnya memang kecil, tapi berharga bagi para pekerja upahan di perkotaan yang tidak memiliki pengalaman tentang akumulasi modal."

Namun, sekalipun koperasi telah tumbuh dengan bergairah, belum ada regulasi apa-apa terkait koperasi ketika itu. Hingga, untuk mengantisipasi perkembangan koperasi yang sudah mulai memasyarakat, pemerintah Hindia Belanda mengeluarkan peraturan perundangan tentang perkoperasian. Pertama, diterbitkan Peraturan Perkumpulan Koperasi No. 43, Tahun 1915, lalu pada tahun 1927 dikeluarkan pula Peraturan No. 91, Tahun 1927, yang mengatur Perkumpulan-
Perkumpulan Koperasi bagi golongan Bumiputra. Undang-undang ini lahir melalui melalui perjuangan yang cukup panjang. Melalui peraturan tersebut maka izin mendirikan koperasi diperlonggar.

Tentang regulasi ini MadjalabTani melaporkan:

"Bahasa baroe-baroe ini soedah berlakoe (didjalankan) sebuah undang-udang tentang peraturan perkumpulanperkumpulan komperasi bumiputra. Maksudnya ialah untuk mempermudah segala syarat-syarat yag perlu buat mendirikan koperasi."

Namun, pada tahun 1933, Pemerintah Hindia-Belanda menetapkan regulasi baru, Peraturan Umum Perkumpulan-Perkumpulan Koperasi No. 21, Tahun 1933. Peraturan tahun 1933 itu hanya diberlakukan bagi golongan yang tunduk kepada tatanan hukum Barat, sedangkan Peraturan tahun 1927, berlaku bagi golongan bumiputra. Diskriminasi pun diberlakukan pada tataran kehidupan berkoperasi, sehingga alih-alih menumbuhkan gairah perkoperasian malah justru mematikan usaha koperasi itu sendiri. Dengan mengeluarkan regulasi terbaru ini, pemerintah jajahan dianggap ragu-ragu menganjurkan koperasi karena pertimbangan politik, bahwa pemerintah jajahan khawatir koperasi itu akan digunakan oleh kaum politik untuk tujuan yang menggalang kekuatan kaum bumiputra merongrong kekuasaan pemerintah jajahan (Dahlan Djas: 26-27).

$$
\text { Pada tahun 1942, ketika Jepang }
$$
menduduki Indonesia, perkembangan koperasi juga tidaklah menggembirakan. Jepang memang mendirikan koperasi dengan nama kumiyai. Awalnya koperasi ini berjalan baik, namun fungsinya berubah drastis menjadi alat Jepang untuk mengeruk keuntungan, dan menyengsarakan rakyat Indonesia. Koperasi pada masa ini difungsikan sebagai distributor bahan-bahan kebutuhan pokok untuk kepentingan perang Jepang. 
Usaha koperasi harus disesuaikan dengan azas kemiliteran Jepang. Akibatnya, sangat merugikan bagi para anggota dan masyarakat pada umumnya. Semua koperasi yang didirikan berdasarkan peraturan pemerintah Belanda harus mendapat persetujuan dari pihak Jepang (Ahmad Zakarsi, 2012: 7).

Setelah Indonesia merdeka, melalui prakarsa Hatta pada 1947, pertumbuhan koperasi mendapat persemaiannya di tanah yang layak. Kata Hatta, masyarakat Nusantara adalah masyarakat: “ ... tolong menolong! Sanubari rakyat Indonesia penuh dengan rasa bersama, kolektiviteit ...." (Hatta, 1923: 98).Pemerintah yang baru, terutama ketika Hatta menjadi Perdana Menteri, memberi stimulus yang memadai terhadap koperasi. Undang-undang sendiri menjamin kehadirannya dan koperasi dijadikan sokoguru ekonomi bangsa. John menulis: “... setelah kemerdekaan, organisasi simpan pinjam masyarakat skala kecil berkembang dengan pesat. Koperasi, tabungan lokal dan perkumpulan masyarakat bagi jaminan kematian serta sarekat buruh yang mengelola dana bantuan, semuanya tumbuh dengan cepat."

Tapi, apa mau dikata, seiring waktu berjalan, nafas koperasi ngos-ngosan meniti tanjakan zaman. Tidak banyak koperasi yang berhasil selamat dari keambrukan. Arus ekonomi bergerak ke arah yang berbeda di mana sistem-kapital telah menjadi ruh yang membentuk dan menghidupi dunia. Sekarang, koperasi bukan lagi sebuah pilihan yang menjanjikan untuk melawan dominasi kepentingan ekonomi global yang semakin mapan. Sehingga muncul adigium: "Kapitalisme tak bisa dilawan, ia hanya bisa diiringi!"

\section{BIBLIOGRAFI}

Anthony Reid. 1992. Asia Dalam Kurun Niaga 1450-1680 Jilid 1: Tanah di bawah angin', 1992 Jakarta: Yayasan Obor Indonesia.

Christhoper Lloyd. 1993. The Structure of History. Cambridge. Blackwell.

Christine Dobbin. 1977. "Economic change in Minangkabau as a factor in the Rise of the Padri Movement, 17841830",Indonesia, No. 23 (April).

ChristineDobbin. 2008. Gejolak Ekonomi, Kebangkitan Islam dan PerangPadri. Jakarta: KomunitasBambu.

Dedi Arsa, 2018. Celana Pendek dan Cerita Pendek. Yogyakarta: Basabasi Press.

Gilbert J. Garaghan. 1984. A. Guide to Historical Method. New York: Fordham University Press.

H. Nugroho. 2001. Uang, Rentenir, dan Hutang Piutang di Jawa. Pustaka Pelajar: Yogyakarta.

Herlina Setiyarini. 2014. "Pemikiran Mohammad Hatta tentang Ekonomi Koperasi Tahun 1925-1953", Avatara, Journal Pendidikan Sejarah Volume 2, No. 3, Oktober. hlm. 211-223

J. H. Boeke. 1983. Prakapitalisme di Asia. Jakarta: Sinar Harapan \& Yayasan Tani Atsiri Wangi.

J.B.A.F. Mayor Polak. 1964. Sosiologi. Pengantar Ringkas. Jakarta: Ichtiar

John Ingleson. 2013. Perkotaan, Masalah Sosial, dan Perburuban di Jawa Masa Kolonial. Jakarta: Komunitas Bambu.

Kuntowijoyo. 2003. Metodologi Sejarah. Yogayakarta: Tiara Wacana.

Madjalah Tani, 15-22 Agustus 1929.

Madjalah Tani, 23 Juli-30 Juli 1928

Majalah Tempo, 12 Agustus 2002.

Melani Budianta. 2002. "In the Margin of the Capital: From 'Tjerita Boedjang Bingoeng' to 'Si Doel anak sekolahan'. Keith Foulcher \& Tony Day (editor) In Clearing a Space:Postcolonial Readings of Modern Indonesian Literature, hlm. 237272. Leiden: KITLV. 
Mestika Zed dkk., 2012. Cara Baik Bung Hatta. Padang: UNP Press.

Mestika Zed, 2012. "Dilemma Ekonomi Melayu: Dari Melayu Kopi Daun Hingga Kapitalisme Global", Tingkap, Vol 6, No 2, hlm. 67-78

Mohammad Hatta. 1953. Kumpulan Karangan Jilid I. Jakarta: Bulan Bintang

Mohammad Hatta. 1978. Memoir. . Jakarta:

Titianmas Indonesia

Pandji Poestaka, 1 Juli 1923

Pandji Poestaka, 27 Agustus 1926

Pandji Poestaka,8 Februari 1927

Peter Boomgaard. 1989. Anak Jajahan Belanda:

Sejarah Sosial dan Ekonomi Jawa 1795. 1886. Jakarta: PT Djambatan.

Ramon Guillermo. 2014. "Themes of Invention, Help, and Will: Joachim Campe's Robinson der Jüngere in Tagalog andBahasa Melayu Translations", Southeast Asian Studies, Vol. 3, No. 1, April, hlm. 3-47

Sartono Kartodirdjo. 1993.Pendekatan Ilmu Sosial dalam Metodologi Sejarah.Jakarta: Gramedia.

Yuval Noah Harari. 2017. Sapiens: A Brief History of Humankind. Jakarta: Alvabet. 